\title{
Organizational Commitment Survey: A Confirmatory Factorial Analysis Based on Vocational Colleges Teachers Sample
}

\author{
Mohamad Zaid Mustafa, Yahya Buntat, Muhammad Ashraf Omar, Abdul Rasid Abdul Razzaq, \\ Rosnee Ahad
}

\begin{abstract}
This study was conducted to verify the construct model for organizational commitment among technical teachers at the Vocational College under the Ministry of Education. A study involving 25 vocational colleges with a total sample of 493 people consisting of teachers in mechanical engineering, electrical and electronic engineering fields, and engineering. This study uses Structural Equation Modeling (SEM) approach with AMOS 20 software. Researchers used the Organizational Commitment Questionnaire (OCQ) developed by Meyer, Allen, and Smith (1993) and Meyer and Allen (1997), comprising three substructures namely affective commitment, normative commitment and continuous commitment. The number of items is 24, 8 items per sub construct and after exploratory factor analysis is carried out there were only 22 items left. In order to ensure that the organization's commitment measuring model is verified, three factors have been evaluated as unidimensionality (looking at the factor loading $\geq 0.6$ ), Validity (convergent validity $A V E \geq 0.5$, and construct validity refers to fitness indexes) and Reliability (composite reliability, $C R \geq 0.6$ and Average Variance Extracted $\geq 0.5$ ). After the CFA analysis is carried out no items were dropped because all items have loading factors $>0.6, A V E \geq$ 0.5 values for all sub constructs. While fitness indexes for Absolute Fit $(\mathrm{RMESA}=0.062)$, Incremental Fit $(\mathrm{CFI}=0.953$, $T L I=0.945)$ and Parsimonious Fit (Chisq/df $=2.918)$ met the requirements set for all $C R$ values $\geq 0.6$. It can be concluded that after the measurement model was modified by looping between items, the model was fit to be used for structural model analysis process.
\end{abstract}

Index Terms: Organizational Commitment.

\section{INTRODUCTION}

Implementation of the Vocational Education Transformation Plan divided into the surge phase (20112013), improvement phase (2014-2016) and the empowerment phase (2017-2020) has led to a major change to the education system in Vocational Secondary Schools, has also been transformed into Vocational College ( KV) (KPM, 2011). Transformation in $71 \mathrm{KVs}$ has led to changes in curriculum structure, co-curriculum, work time, assessment system, student recruitment process, infrastructure, level of education, human resources,

Revised Manuscript Received on April 19, 2019.

Mohamad Zaid Mustafa, Faculty of Technical and Vocational Education, Universiti Tun Hussein Onn Malaysia, Johor, Malaysia.

Yahya Buntat, Faculty of Education, Universiti Teknologi Malaysia Johor, Malaysia.

Muhammad Ashraf Omar, Centre For Language Studies, Universiti Tun Hussein Onn Malaysia, Johor, Malaysia.

Abdul Rasid Abdul Razzaq, Faculty of Technical and Vocational Education, Universiti Tun Hussein Onn Malaysia, Johor, Malaysia.

Rosnee Ahad, Faculty of Technical and Vocational Education, Universiti Tun Hussein Onn Malaysia, Johor, Malaysia. administrative system, 5S system, and more (BPTV, 2012). In implementing the transformation involving all administrators and teachers in $\mathrm{KV}$, the results of the interviews and joint researches with teachers and directors in ten KVs shows that technical teachers are more involved This involvement is due to changes in the curriculum to enable students to be certified with Malaysian Skills Certificate (SKM), which increases teaching and learning skills. This view is parallel to Stasz et al., (2004) stating that the nature and depth of learning on the technical program is variable according to the desired skill level. In order to achieve high quality technical education system and effective teaching and learning process, the education system should be directed by quality and committed teachers and leaders (Barber \& Mourshed, 2007).

More clearly these technical teachers are involved in workshops during teaching and learning sessions and these technical teachers are not provided with laboratory assistants such as teachers teaching science subjects (Sharifah et al., 2013). According to Azarudin (2004), the teachers involved in managing the workshops have other burden of duties such as being the class teacher, subject committee and handling co-curriculum. In addition to the teaching task, the teacher is also tasked with managing workshops, responsible for equipment, inventory, storage, $5 \mathrm{~S}$ and workshop cleanliness and this indirectly affects their job satisfaction (Azarudin, 2004). This phenomenon is in line with Christina Boateng (2012)'s view that the nature and characteristics of technical education presents unique challenges to administrators and organizations, whereby technical institutions require workshops, tools, equipment, and raw materials that will add workload for the teachers.

Christina Boateng (2012) also noted that technical subjects require sufficient time for students' preparation and practice in addition to the different ways to assess the students' competence in different skills. All this makes technical education more complicated than the usual education system (Christina Boateng, 2012). According to Sanderson et al., (2000), technical teachers play a role that is different compared to other academic teachers, as the skills possessed by these technical teachers can contribute opportunities to venture into business and the industry with a more rewarding salary and welfare than the teaching profession. According to Sanderson et al., (2000) in his research in the United States finds out that 41.3 percent of

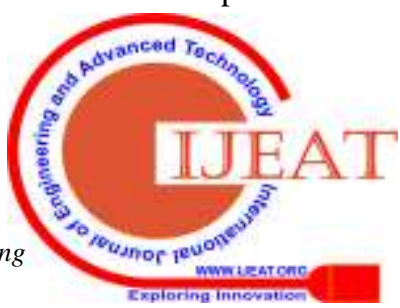


technical teachers have expressed their intention to leave the teaching profession to venture into another profession.

Finland is a country with the best educational system in the world as the result of having committed and outstanding teachers in the process of education transformation (Sahlberg, 2010). Schools in Finland have played an important role in transforming Finland from a traditional farming country to a k-economy innovation based industry who are committed to the planning of the Finnish government transformation (Sahlberg, 2010). Lokman et al., (2012) states that the excellence of a school has a close organization. According to Lokman (2012), this commitment further refers to the individual who accepts the goal, the willingness to make something on behalf of the organization and has a high desire to remain with the organization.

The transformation of vocational education at $\mathrm{KV}$ beginning in 2012 wherein the main focus of the early stage is to ensure the implementation of vocational education transformation in 15 Vocational College $(\mathrm{KV})$ pilot can run smoothly (BPTV, 2012). The five main strategies in this transformation are: 1) providing a vocational education curriculum that can produce skilled human capital, 2) develop a strong vocational education institute, 3) collaboration with strategic partners, 4) provide assessments that are recognized for vocational education graduates, and 5) the empowerment of vocational education management organizations (BPTV, 2012). Syed Sofian and Rohany Nasir (2010) explain that the implementation of education transformation makes the role and responsibility of teachers greater, challenging and more complex. This is due to the changes in curriculum structure, co-curriculum and community expectations towards teachers are exceptionally high, and so teachers need to give the highest commitment so that every proposed transformation will succeed.

In fulfilling the process of transformation of vocational education in $\mathrm{KV}$, commitment among teachers was paramount as commitment was a serious focus that would lead to excellent work quality (Yahya Don et al., 2006). Teachers' commitment to school is a key thrust in determining the success of the transformation of a country's education system because teachers are the implementers of every educational policy that has been enacted (DiPaola et al., 2005; Leithwood et al., 2006). Firestone and Rosenbaum (1998) stated that the commitment in the education system was the emotional and affective reaction of the teacher to the teaching profession, while Mowday et al. (1982), Downs (1991) and Gamon (1991) proposed obedience and adherence to school, profession, values and work ethics. According to Lokman et al., (2012), teachers with high commitment will always be positive and respond to calls for transformation proposed by the government.

Commitment to the organization is a measure of initial information on their acceptance of the organization through increased productivity (Meyer \& Allen 1997). According to Potvin (1991), staff with high commitments are more concerned with the task of fulfilling the organizational sense than their own needs, otherwise, a low country and this achievement was made possible by teachers relationship with the teacher's commitment to the acceptance of employees to the organization and provides

level commitment staff would delay work, not be at work, prioritizing personal matters and not wanting to work over time. According to Mintzberg (1983), commitment has to do with the achievement of organizational goals, so a successful organization is an organization with its members committed to the mission and vision of the organization. The study of Coladarci (1992), Kushman (1992), and Rosenholtz, (1989) demonstrated the strong link between commitment and work culture in schools that brought success to the school. Teachers' commitment is also closely linked to school effectiveness, work achievement, job satisfaction, and more importantly the achievement of students (Nir, 2002; Louis, 1998; Singh \& Billinsgley, 1998; Firestone \& Pennell, 1993). Hence, committed teachers are more motivated to make the transformation, responsible more attentive, dedicated, and more sincere in their work (Elliot \&Crosswell, 2003; Firestone \& Pennell, 1993).

In ensuring that the transformation of vocational education succeeds issues related to organizational commitment that can lead to action beyond control need to be addressed. Previous studies show that organizational success is influenced by organizational commitment (Janis, 2013; Norshidah, 2012; Noorhafeza \& Ferlis, 2010; Rozman et al., 2010; Ashkan Khalili, 2011 \& Florence Fletcher, 2007).

Organizational commitment can be defined as one's desire to remain with organizations involving psychological ties between workers and organizations (Noraishah, 2010). While Mathis and Jackson (2003) define organizational commitment as the level of trust and acceptance of the workload towards the goals and goals of the organization as well as the desire to remain in the organization. Organizational commitment is a measure of the desire to be a member of the organization and a desire to the highest level of expertise in the organization (Robbins \& Judge, 2007; Metcalf \& Dick, 2000). Lee and Miller (2001) define organizational commitment as a sense of trust in organizational values, willingness to do their best for the benefit of the organization and the desire to remain with the organization.

Mowday et al., (1982) and Porter (1974) define organizational commitment as the acceptance of the people within an organization to involve itself into the organizational structure. According to Mowday et al., (1982), the commitment to this organization can be illustrated through three factors which are acceptance of organizational values and goals, preparation and willingness to work solemnly on behalf of the organization and the desire to maintain membership within the organization. O'Reilly (1989) defines organizational commitment as an individual loyal to the organization and its values and engage in work within the organization.

\section{ORGANIZATIONAL COMMITMENT THEORY}

Research on organizational commitment is an ongoing study to date as it relates to individual performance, 
organizational performance and effectiveness in an organization (Mohamed Mousa \& Ruth Alas, 2016; Allen \& Meyer, 1996; Mathieu \& Zajac, 1990; Mowday, 1998) commitment is translated into three categories, namely work commitment, career commitment, and organizational commitment. The definition of organizational commitment refers to the strength of individual identification and its involvement in the organization (Porter et al., 1974). According to Vandenberghe and Tremblay (2008), the model of organizational commitment proposed by Meyer and Allen (1991) is the most popular model used in previous studies. The organizational commitment model proposed by Meyer and Allen (1991) has three dimensions of affective commitment, continuous commitment and normative commitment.

Meyer and Allen (1991) state that organizational commitment is the psychological relationship of workers to the organization and has implications to stay within the organization or vice versa. The study of Cohen (1991) and Mathieu and Zajac (1990) found that organizational commitment had a positive relationship with performance in work. While the Meyer and Allen models (1991) are the most popular models used in previous studies, however, this study presents three models of organizational commitment: 1) Meyer and Allen Organization Commitment Model (1991), 2) The Steers Organization Commitment Model (1977) and 3) McGregor model (2005).

\section{A. Meyer and Allen's Organizational Commitment}

The three-dimensional organizational commitment model developed by Meyer and Allen in 1991 can be said to dominate the organizational commitment research (Meyer et al., 2002). The three dimensions stated by Meyer and Allen (1997) are effective commitments, continual commitment and normative commitments. Meyer and Allen (1997) are of the view that affective commitments, ongoing commitment, and normative commitments are due to the inherent disparity among the employees.

\section{(i) Continuous Commitment}

Meyer and Alen (1997) explain continuous commitment based on profit-loss concepts that are considered when individuals are in an organization. The continued commitment according to Meyer and Alen (1997) is also based on the intentions of a person to remain in the organization due to the difficulty of obtaining other jobs if it ceases from the current organization. This constant commitment actually states that one's obligation to stay with the organization is based on financial resources if it stops from the organization (Allen \& Meyer, 1990; Meyer \& Allen, 1991, 1997). Meyer and Allen (2002) also point out that constant commitment is said to occur when a worker stays with an organization due to the lack of alternative income if they left the organization, such as loss of income, seniority or retirement benefits. Continuous commitment is the desire that individuals have to endure in the organization, so that individuals feel themselves with the organization (Bishop, 2000). It can be summarized that continuous commitment will be impaired by withdrawing from the organization due to loss of retirement benefits and others.

\section{(ii) Normative Commitment}

Normative commitment is the resulting commitment when one remains in organizational due to pressure from others to continue working within the organization (Meyer \& Alen, 1997). Meyer and Alen (1997) also point out that a person who is at a high level of normative commitment is very concerned with the views of others against himself to stay within the organization or vice versa. Normative commitment is based on the norms of the employee, the sense of self confidence will make the individual responsible for the organization and feel that they must continue to be in the organization on the basis of loyalty to the organization. These normative commitments can thrive when organizations offer rewards, such as financing courses or providing training centres to train their employees on an ongoing basis (Meyer \& Allen, 1991).

Normative commitment is also developed when one pioneers an organization and has been with the organization for a long time and therefore is more responsible to the organization (Meyer et al., 2002). Jaros (1997) states that normative commitments can show the extent to which workers are aligned with the goals of the organization and how the employees will be with the organization. Work experience is believed to contribute to the development of normative commitments as well as organizational support, fairness and clarity of the role of workers in the organization (Meyer et al., 2002). Normative commitment is important because it relates to organizational success and create a working climate within the organization (Meyer et al., 2002; Iverson \&Buttigieg, 1999). This commitment is also linked to daily social culture and can be influenced by socialization within the individual family and culture before and after the organization (Allen \& Meyer, 1996; Schappe \& Doran, 1997).

\section{(iii) Affective Commitment}

Meyer and Allen (1997), states that affective commitment is related to the individual's desire to be bound by the organization on his own desire and will. Affective commitment basically refers to a person who remains in the organization for his strong beliefs with the goals and values practiced by the organization. Workers who are on the level of affective commitments are individuals who are happy because they are satisfied with the organization and willing to contribute anything for the benefit of the organization. Affective commitment shows the extent to which individuals are engaged and familiar with the organization. Affective commitment is the most powerful in relation to work and influence positive behaviours among employees for example workplace attendance, work performance, willingness to accept trust and general good behaviours (Meyer et al., 2002).

Affective commitment will have a positive impact on the organization (Powell \& Meyer, 2004). It can be a measure of the relative strength of an individual's involvement with the organization (Mowday et al., 1979). Mathieu and Zajac (1990) state that the features in affective commitment are 
profound beliefs about the organization, the acceptance of goals and values in the organization, working strongly for the organization and the desire to succeed in the organization. The components in this organizational commitment can be experienced at various stages at the same time (Meyer \& Allen, 1991). Of the three domains of commitment proposed by Meyer and Allen (1997), the dimensions of affective commitments have the best impact on employees and organizations. The study conducted by Meyer and Allen (1997) and Mathieu and Zajac (1990) explains that there is a good but weak relationship between affective commitment and work performance. This organizational commitment component is characterized by a different set of minds and may have different implications in the behaviour of the work (Meyer \& Allen, 1991; Powell \& Meyer, 2004).

\section{B. Steers Organization Commitment}

Employee's commitment to the organization model proposed by Steers (1977) relates to the results of employee commitment to the organization when the employee continues to serve in the same organization over a long period of time. He presents several personal factors related to the employee's commitment to the organization, among others:

\section{(i) Age and Gender}

According to Welsch and La Van (2001) mature and long-term employees will be highly committed to the organization as opposed to new employees. She also stated that female workers would give higher organizational commitment than men.

\section{(ii) Educational Background}

Steers (1977) also noted that less-qualified employees are more committed to the organization than those with higher qualification. This may be as those who are higher qualified feels it is easier for them to seek work in other organizations than those with lower qualifications

\section{(iii) Organizational Structure}

According to Steers (1977) and Buchanan (1974) work experience possessed by a person would make the individual very important to the organization. Workers will also be more committed to the organization if the organizational management gives the employee confidence in the task given and empowers his / her self-determination to complete the work given.

\section{(iv) Task Responsibility}

The task responsibility is related to the scope of work that can be enriched through job enrichment. Job enrichment can encourage and assist workers to increase their commitment to the organization to a higher level. This method is also effective by empowering employees to make decisions. Job enrichment can also increase responsibility for the task, making the worker more skilled and expert in the field and able to accomplish heavier task in his own way.

\section{(v) Welfare}

Workers will feel appreciated if the organization cares about its virtues. Organizations will also be involved as

employees will give higher organizational commitment. This is because employees think the organization can be expected to help them in any case. The organization will look forward to seeing the experience of its employees seen as an important force to help improve the organization (Steer \& Porter, 1991).

\section{McGregor Model}

$\mathrm{X}$ Theory and $\mathrm{Y}$ Theory are human motivational theories developed by Douglas McGregor in 1960 and have been used in human resource management, organizational behavior, organizational communication and organizational development. $\mathrm{X}$ Theory is the negative impression of the employer on its employees, $\mathrm{Y}$ Theory is the positive impression of the employer. The $\mathrm{X}$ theory is based on the conclusions made by McGregor based on the management's views as a result of the study conducted by Taylor, Fayol and Weber, meanwhile $\mathrm{Y}$ Theory is the result of the conclusions by McGregor based on the study of human behavior conducted by Elton Mayo and Mary Parker Follet. The details of the indicators for these theories are as shown in Table $\mathbf{I}$.

\section{Table I. McGregor's X Theory and Y Theory}

\section{Theory}

- Employers do not like their work and should avoid working.

- The worker is just waiting for instructions and has no ambition.

- Employees are constantly under control, forced, and threatened with various penalties for the purpose of achieving the goals of the organization.

- Employees are constantly avoiding accountability to the organization as well as not adhering to the organization's need.

- Employees are not highly intellectual and less-creative.

In general, the XY Theory presented by McGregor in 1960 remains a major theory in organizational development and organizational culture. Theory $\mathrm{X}$ refers to how to manage human resources using force. According to this theory, workers in this group do not like to work. They will perform the task if the punishment will follow if they fail to do the job. They will only follow the instructions and will

\section{Y Theory}

- Employees see work as something natural like relaxing and playing.

- Employees have high ambitions and dislike orders.

- Highly motivated employees and do not require continuous supervision.

- Employees want responsibility and fee proud when successful.

- Workers are creative. Published By:
Blue Eyes Intelligence Engineering
\& Sciences Publication 
seek opportunities to avoid work. According to the $\mathrm{Y}$ theory, it is suggested that an integration of the goals of an individual and the purpose of the work should be made with emphasis on the application of human values. With these values, the workers are able to direct themselves to accomplish their tasks and achieve organizational goals as well as gain job satisfaction. Salary and incentive systems are created with the aim of influencing workers in this group to maintain their ability to work well. Such workers will find opportunities to contribute more. Hence, if they are given the opportunity and encouragement to use their creativity when solving problems and being applied with humanitarian values, their ability as a quality workforce will be more prominent.

In general, the XY theory presented by McGregor in 1960 remains a major theory in organizational development and organizational culture. Theory $\mathrm{X}$ refers to how to manage human resources using force. According to this theory, workers in this group do not like to work. They will perform the task if the punishment will follow if they fail to do the job. They will only follow the instructions and will seek opportunities to avoid work. According to the Y theory, it is suggested that an integration of the goals of an individual and the purpose of the work should be made with emphasis on the application of human values. With these values, the workers are able to direct themselves to accomplish their tasks and achieve organizational goals as well as gain job satisfaction. Salary and incentive systems are created with the aim of influencing workers in this group to maintain their ability to work well. Such workers will find opportunities to contribute more. Hence, if they are given the opportunity and encouragement to use their creativity when solving problems and being applied with humanitarian values, their ability as a quality workforce will be more prominent.

\section{Questionnaire on Organizational Commitment}

There are two questionnaires to measure the organizational commitment that has always been the choice of previous researchers. The questionnaire developed by Porter et al., (1974) and Meyer and Allen (1997). Questionnaire by Porter et al., (1974) was developed to measure the satisfaction and level of employee engagement in the organization, there were 15 items of 9 scales, this questionnaire did not set a clear boundary between the types of commitments. Hence the questionnaire by Meyer and Allen (1997) is a better choice for measuring organizational commitment. Organizational Commitment Questionnaire by Meyer and Allen (1984) previously suggested to look at the differences between the types of affective commitments and ongoing commitment. Affective commitment is the spirit of belonging and emotion to the organization, while continuing commitment emphasizes the perceived cost of leaving the organization. In 1990 Allen and Meyer later introduced the third component of a normative commitment, reflecting a permanent obligation with the organization. Meyer, Allen and Smith (1993) revise the scale of normative commitments to explain the differences between affective commitments and normative commitments. The original version included 24 items, 8 items for each dimension in organizational commitment questionnaire (Meyer \& Allen,
1984, 1991; Allen \& Meyer, 1990), a later versions by Meyer, Allen, and Smith (1993) and Meyer and Allen (1997) contains only 18 items, 6 items per scale.

The organizational commitment questionnaire is a selfassessment questionnaire responding to each of the 8 items assessed using the Likert scale 5 points with the label: $0=$ strongly disagree, 1 = disagree, $2=$ disagree, $3=$ agree, $4=$ strongly agree. Reliability (Alpha) from organizational commitment questionnaires based on previous studies, Allen and Meyer (1996) reported 0.87 for affective, 0.75 for persistent, and 0.79 for normative. Dunham, Grube, and Castaneda (1994) find alpha range 0.74-0.87 for affective, 0.73-0.81 for continuous, and 0.67-0.78 for normative. Cohen (1991) found Alpha from 0.79 for affective, 0.69 for persistence and 0.65 for normative. Based on this view, the researcher chose to use the 24 item questionnaire developed by Meyer and Allen (1997) to be used in this study.

\section{METHODOLOGY}

In this study, the Structural Equation Modeling (SEM) approach and the Analysis of Moment Structures (AMOS) software in analyzing and verifying the proposed model at the pre-stage of the study were used. This approach has been widely used in several disciplines, including banking, healthcare, information management, logistics, marketing, psychology, and tourism management (Lu et al., 2007). A total of 865 questionnaires were distributed and 609 were returned to researchers. The one-to-one review process on the questionnaires was carried out, only completed questionnaires were taken for analysis. Incomplete questionnaires were removed from data processing, out of 609 questionnaires received, 23 of them were incomplete, and a total of 586 questionnaires were used for data analysis.

\section{RESULTS AND FINDING}

\section{A. Outlier Data}

A total of 586 completed questionnaires were submitted on SPSS version 20 and subsequently using the AMOS version 21 software. Outlier data is done by observing the most distant value of the center (Mahalanobis Distance) (Faith Ghozali, 2008; Tabachnick and Fidell, 2007). The criterion used is based on the value of Chi-squares Distribution Table on the degree of freedom, the number of construct items at the significant level of $\mathrm{p}<0.001$ as suggested by Tabachnick and Fidell, (2001). The value of Mahalanobis Distance in this study is $\mathrm{x} 2=143.344$, $\mathrm{df}=95$, $\mathrm{p}<0.001$ ), where the Mahalanobis Distance value greater than 143.3.44 is the data that is out lies and discarded from the data for analysis. Finally, as many as 493 sets of data are desirable to be analyzed, the remaining sample sizes still met the criteria of the minimum sample size survey proposed by Hair et al., (2006). 


\section{B. Normality Test}

Normality tests were carried out on data after the isolation process, the researchers used the skewness and kurtosis method (Hishamuddin, 2005 \& Zainudin, 2015). The data are normally distributed if the skewness and kurtosis values are within the range of \pm 1 (Zainudin, 2012; Hisyamuddin, 2005). According to Zainudin (2015), if samples are over 200 skewness and kurtosis values can be up to \pm 1.5 . While Tabachnick and Fidell (2007) suggest data normality based on skewness and kurtosis values at \pm 2 range for large samples. In this study, researchers use what Tabachnick and Fidell (2007) suggest, as a result of the norms of the study data show all values are within the permissible range.

\section{Confirmatory Factorial Analysis (CFA)}

The CFA analysis is conducted to answer the question of the study to verify the measurement model of organizational commitment in the field of technical teachers in electrical and electronics engineering, civil engineering and mechanical engineering at Vocational College, KPM. To ensure this measurement model can be used there are three things in the value, 1) Unidimensionality (see loading factor value $\geq 0.6$ ), 2) Validity (convergent validity $\mathrm{AVE} \geq 0.5$, construct validity refers to fitness indexes and discriminant validity) and 3 ) Reliability (composite reliability, $\mathrm{CR} \geq 0.6$ and Average Variance Extracted $\geq 0.5$ ) (Zainudin, 2015). According to Zainudin (2015) discriminant validity is only calculated for the combined model and only the main constructs. Composite Reliability (CR) and Average Variance Extracted (AVE) are calculated using the formula, $\mathrm{CR}=(\Sigma \mathrm{K}) 2 /[(\Sigma \mathrm{K}) 2+(\Sigma 1-\mathrm{K} 2)]$ and AVE $=\Sigma \mathrm{K} 2 /$ loading of each item and $n$ is the number of items in the measurement model.

Fitness Index measurement model is based on (i) RMSE $\leq$ 0.008 (The Root Mean Square of Error Approximation) (ii)
IFI $\geq 0.9$ (Incremental Fit Index) (iii) CFI $\geq 0.9$ (Comparative of Fit Index) 0.9 (Tucker Lewis Index) and (v) Chisq / df $\leq 3.0$ (Chi Square / Degress of Fredom). If the analyzed model is less matched, Zainudin (2015) and Hair et all., (2006) recommends that modifications to the model be performed by checking the loading factor for each item to exceed 0.6, items less 0.6 should be dropped and if the match index has not been reached revision to the modification index (MI) based on $\mathrm{MI} \geq 15$, the item needs to be boiled.

The verification factor analysis (CFA) was conducted to confirm the organizational commitment constructs instruments. As a result of the EFA analysis there are 3 subconstructs, namely affective commitment, continuous commitment and normative commitment. The purpose of this CFA analysis is to examine the integrity of the organization's commitment measurement model that has 22 items. After data is analyzed, the findings of the organization's commitment measurement model are shown in Fig I. To answer sub-questions of the research such as what is the measurement model developed by unidimensionality? What is the measurement model developed validity? And what is the measurement model developed reliability? Hence, following analysis has been carried out.

\section{a) Unidimensionality}

To ensure that the organizational development construct model is unidimensionality, all items that measure construct or sub-construct need to have loading factor $\geq 0.6$, any item which $<0.6$ needs to be removed. Fig I. shows the loading factor for all items for organizational commitment constructs. Result shows, all items have factor loading $\geq 0.6$, hence no item is dropped.

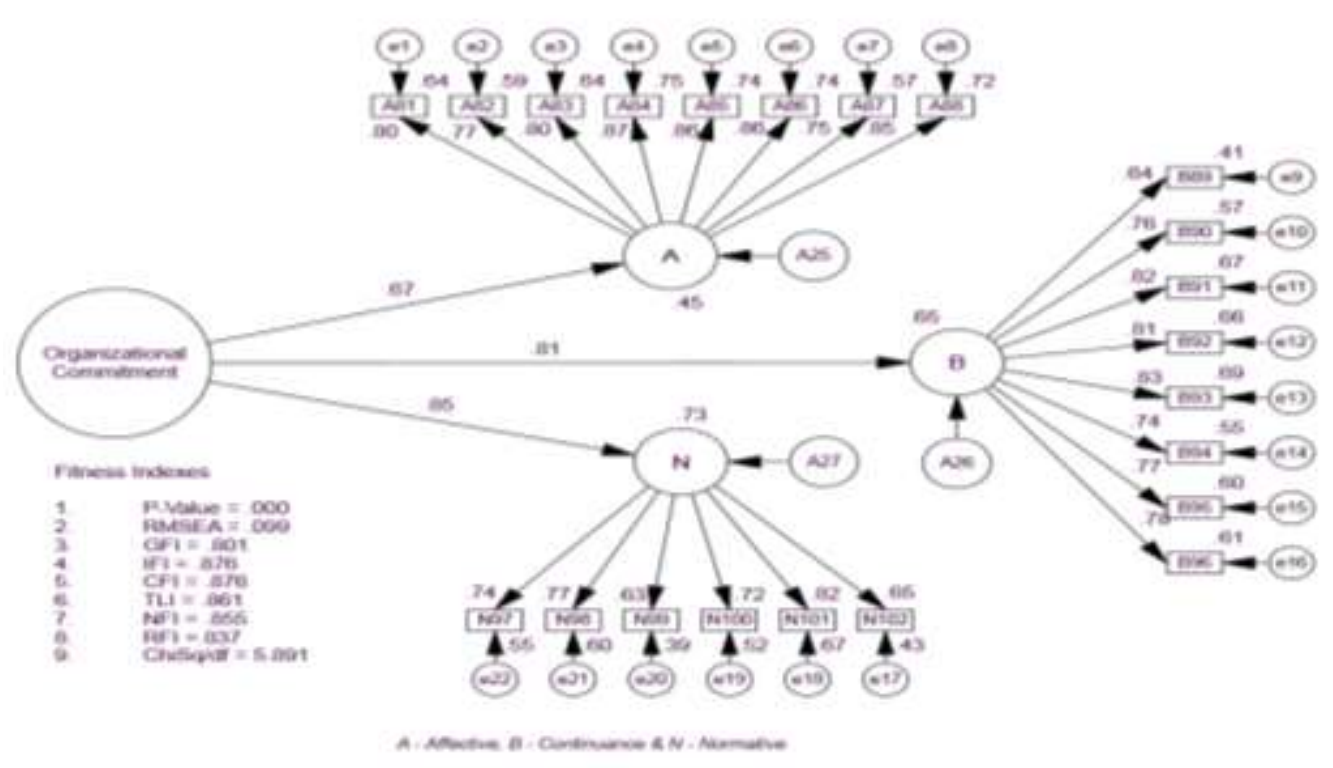

Fig I. Organization Commitment Measurement Model 


\section{b) Validity}

To ensure the model's validity, construct validity, convergent validity and discriminate validity are executed. The validity constraints will be fulfilled when the fitness indexs according to the prescribed conditions, refer to Fig I compatibility index for the model has not reached the prescribed level of RMSEA $=0.098, \mathrm{CFI}=0.880$ and Chisq / $\mathrm{df}=5.706$. Thus, to ensure that the matching index is fulfilled, this model needs to be modified by looking at the Modification Index (MI) value. The looping process of the item is run on the highest MI so fitness indexes are met. The items that need to be run in this process are as shown in Table II, this step is done one by one until the fitness index is satisfactory, between the item is N98 with N99, B94 with B95, B91 with B92, B90 with B91, B89 with B90, A87 with A88 and A81 with A82. After the measurement model is reanalyzed the modified model as shown in Fig II, the fitness index reads value is $\mathrm{RMSEA}=0.062, \mathrm{CFI}=0.953$ and Chisq/df $=2.918$, all of these values have met the minimum requirement as shown in Table III.

Table II. Modification Index for Organizational Commitment Item

\begin{tabular}{|c|c|c|c|c|}
\hline & & M.I. & $\begin{array}{c}\text { Par } \\
\text { Chang } \\
\text { e }\end{array}$ & Comment \\
\hline $20<-->$ & $\mathrm{e} 21$ & 27.817 & -.117 & $\begin{array}{c}\text { Item N98 and N99 } \\
\text { redundant }\end{array}$ \\
\hline $5<-->$ & e16 & 16.733 & .062 & \\
\hline $14<-->$ & e15 & 162.636 & .234 & $\begin{array}{c}\text { Item B94 and B95 } \\
\text { redundant }\end{array}$ \\
\hline $11<-->$ & e15 & 22.014 & -.073 & \\
\hline $1<<->$ & e14 & 21.179 & -.078 & \\
\hline $1<-->$ & e12 & 21.022 & .067 & $\begin{array}{c}\text { Item } \mathrm{B} 91 \text { and } \mathrm{B} 92 \\
\text { redundant }\end{array}$ \\
\hline $10<-->$ & $\mathrm{e} 15$ & 16.282 & -.064 & \\
\hline $10<-->$ & e14 & 15.616 & -.068 & \\
\hline $10<-->$ & $\mathrm{e} 12$ & 22.403 & -.070 & \\
\hline $10<->$ & e11 & 31.608 & .082 & $\begin{array}{c}\text { Item } \mathrm{B} 90 \text { and B91 } \\
\text { redundant }\end{array}$ \\
\hline$\langle-->$ & e15 & 15.277 & -.072 & \\
\hline$\langle-->$ & e14 & 17.714 & -.084 & \\
\hline$\langle-->$ & $\mathrm{e} 10$ & 121.674 & .190 & $\begin{array}{c}\text { Item } \mathrm{B} 89 \text { and } \mathrm{B} 90 \\
\text { redundant }\end{array}$ \\
\hline$\langle-->$ & e8 & 77.327 & .067 & $\begin{array}{c}\text { Item } \mathrm{A} 87 \text { and } \mathrm{A} 88 \\
\text { redundant }\end{array}$ \\
\hline$\langle-->$ & e6 & 15.552 & .023 & \\
\hline$\langle-->$ & e9 & 32.625 & .078 & \\
\hline$\langle-->$ & $\mathrm{e} 2$ & 105.107 & .094 & $\begin{array}{c}\text { Item } \mathrm{A} 81 \text { and } \mathrm{A} 82 \\
\text { redundant }\end{array}$ \\
\hline
\end{tabular}

Table III. Fitness Indexes Summary of Organization Commitment Measurement

\begin{tabular}{|c|c|c|c|c|}
\hline Categories & $\begin{array}{c}\text { Names } \\
\text { of } \\
\text { Index }\end{array}$ & $\begin{array}{c}\text { Hypothesis } \\
\text { of Model } \\
\text { Index } \\
\text { Value }\end{array}$ & $\begin{array}{c}\text { Modified } \\
\text { Model } \\
\text { Value } \\
\text { Index }\end{array}$ & Comment \\
\hline \multirow[t]{2}{*}{$\begin{array}{l}\text { Absolute } \\
\text { Fit }\end{array}$} & RMSEA & 0.098 & 0.062 & $\begin{array}{l}\text { Met the } \\
\text { required } \\
\text { level } \\
(\leq 0.08)\end{array}$ \\
\hline & GFI & 0.807 & 0.901 & $\begin{array}{l}\text { Does not } \\
\text { meet the } \\
\text { required } \\
\text { level } \\
(\geq 0.09)\end{array}$ \\
\hline \multirow[t]{2}{*}{$\begin{array}{l}\text { Incremental } \\
\text { Fit }\end{array}$} & CFI & 0.880 & 0.953 & $\begin{array}{l}\text { Met the } \\
\text { required } \\
\text { level } \\
(\geq 0.09)\end{array}$ \\
\hline & TLI & 0.865 & 0.945 & $\begin{array}{l}\text { Met the } \\
\text { required } \\
\text { level } \\
(\geq 0.09)\end{array}$ \\
\hline $\begin{array}{l}\text { Parsimonio } \\
\text { us Fit }\end{array}$ & Chisq/df & 5.706 & 2.918 & $\begin{array}{l}\text { Met the } \\
\text { required } \\
\text { level } \\
(\leq 3.00)\end{array}$ \\
\hline
\end{tabular}

To fulfill the second validity requirement, convergent validity needs to be met by calculating the Average Variance Extracted (AVE) for all constructs and substructures of organizational commitment, when the value of AVE $\geq 0.5$. After the AVE calculation for organizational commitment constructs is 0.626 as summarized in Table IV, for the affective commitment sub-construct 0.653 , subconstruct continuous commitment is 0.576 and the subconstruct of normative commitment is 0.534 , summarized in Table V.

\section{Table IV: CR and AVE for Second Order Constructing Organizational Commitments}

$\begin{array}{ccccc}\text { Construct } & \begin{array}{c}\text { Sub } \\ \text { Construct }\end{array} & \begin{array}{c}\text { Charge } \\ \text { Factor }\end{array} & \begin{array}{c}\text { CR } \\ \mathbf{( \geq 0 . 6 )}\end{array} & \begin{array}{c}\text { AVE } \\ \mathbf{( \geq 0 . 5 )}\end{array} \\ \begin{array}{c}\text { Organizational } \\ \text { Commitments }\end{array} & \begin{array}{c}\mathrm{A} \\ \text { (Affective) } \\ \mathrm{B}\end{array} & 0.67 & 0.832 & 0.626 \\ & \begin{array}{c}\mathrm{B} \\ \text { (Continuous) } \\ \text { N }\end{array} & 0.85 & & \\ & & 0.86 & & \\ \text { (Normative) } & & & \end{array}$




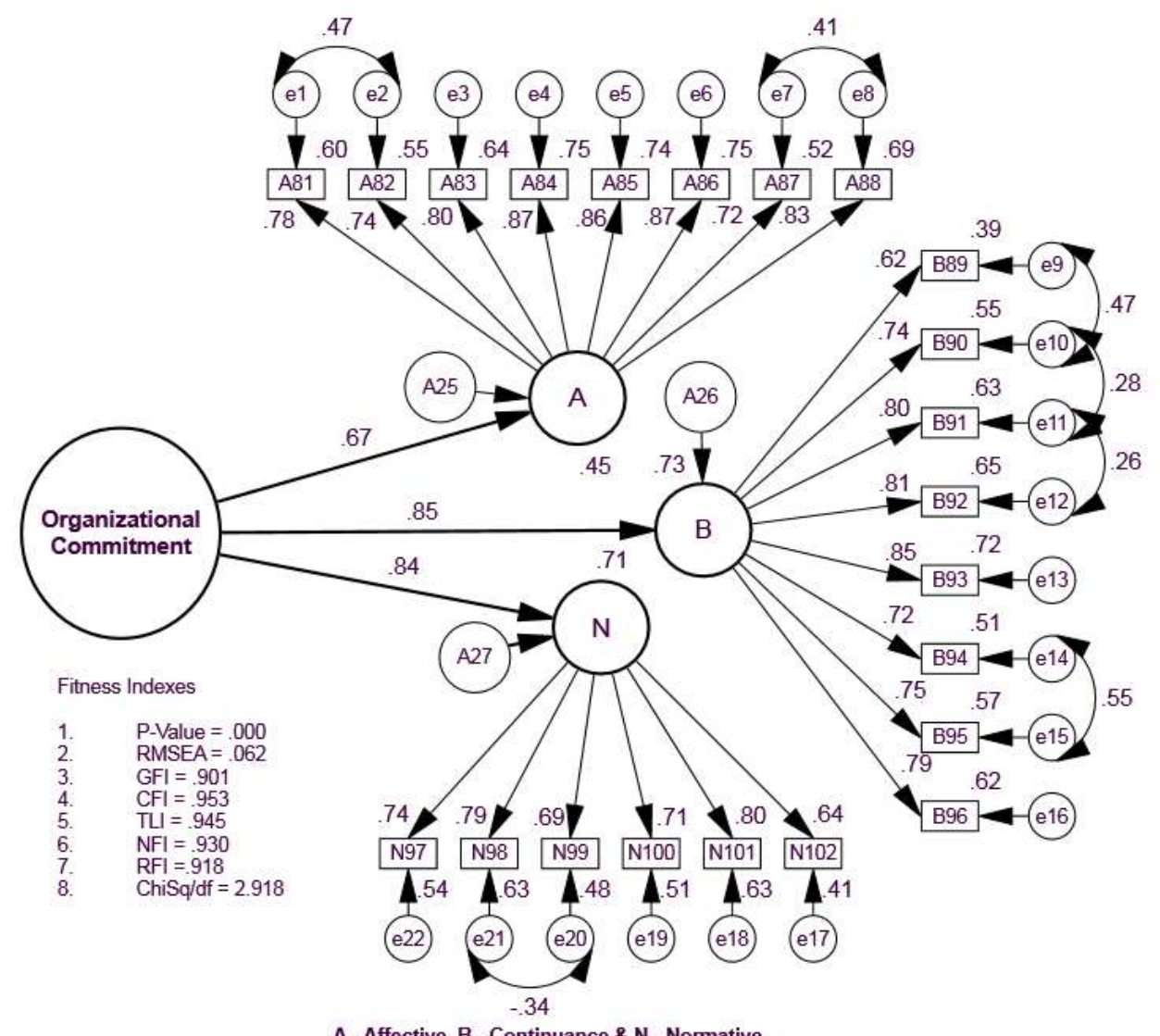

A - Affective, B - Continuance $\&$ N - Normative

Fig II. Customized Organizational Commitment Measurement Model

\section{c) Reliability}

To ensure the reliability model or the extent to which this measurement model is reliable in measuring the latten constructs, it can be determined by calculating the value of Composite Reliability ( $\mathrm{CR} \geq 0.6$ ) which is $\mathrm{CR}$ which demonstrates the reliability of the item and its internal consistency. The findings from the calculation show CR for the organizational commitment constructs is 0.832 , as summarized in Table $\mathrm{V}$, for the affective commitment substructure is 0.945 , for continuous commitment is 0.926 and the normative commitment is 0.872 as summarized in Table V.

Table V. CR and AVE for First Order Constructs Organizational Commitments

$\begin{array}{lllll}\begin{array}{l}\text { Sub } \\ \text { Construct }\end{array} & \text { Item } & \begin{array}{l}\text { Factor } \\ \text { Loading }\end{array} & \begin{array}{l}\text { CR } \\ (\mathbf{0 . 6})\end{array} & \begin{array}{l}\text { AVE } \\ \mathbf{( \geq 0 . 5 )}\end{array} \\ \text { A } & \text { A81 } & 0.78 & 0.945 & 0.653 \\ \text { (Affective) } & \text { A82 } & 0.74 & & \\ & \text { A83 } & 0.80 & & \\ & \text { A84 } & 0.87 & & \\ & \text { A85 } & 0.86 & & \\ & \text { A86 } & 0.87 & & \\ & \text { A87 } & 0.72 & & \\ \text { B } & \text { A88 } & 0.83 & & \\ \text { (Continuous) } & \text { B89 } & 0.62 & 0.926 & 0.576 \\ & \text { B90 } & 0.74 & & \\ & \text { B91 } & 0.80 & & \end{array}$

$\begin{array}{lllll} & \text { B92 } & 0.81 & & \\ & \text { B93 } & 0.85 & & \\ & \text { B94 } & 0.72 & & \\ & \text { B95 } & 0.75 & & \\ \text { N } & \text { B96 } & 0.79 & & \\ \text { (Normative) } & \text { N97 } & 0.74 & 0.872 & 0.534 \\ & \text { N98 } & 0.79 & & \\ & \text { N99 } & 0.69 & & \\ & \text { N100 } & 0.71 & & \\ & \text { N101 } & 0.80 & & \\ & \text { N102 } & 0.64 & \end{array}$

\section{CONCLUSION}

In conclusion, it can be concluded that 493 questionnaires have been analyzed with the total item of 22 items and dropped 2 items during the EFA process, the final item for this measurement model is 22 items. This measurement model can be verified by taking into account the value of 1) unidimensionality (see loading factor value $\geq 0.6$ ), 2) Validity (ie convergent validity $\mathrm{AVE} \geq 0.5$, construct validity refers to fitness indexes and discriminant validity) and 3) Reliability (composite reliability, $\mathrm{CR} \geq 0.6$ and Average Variance Extracted $\geq 0.5$ ). The findings show that all conditions have been fulfilled.

Published By: 


\section{ACKNOWLEDGMENT}

Thank you for team member in Faculty of Technical and Vocational (FPTV), UTHM for support idea and knowledge. This paper received fund from PPG Grant at Universiti Tun Hussein Onn Malaysia (V015).

\section{REFERENCES}

1. Azarudin (2004). Beban Tugas Guru Bengkel Dalam Pengurusan Bengkel Di Lima Buah Sekolah Menengah Teknik Di Negeri Sembilan. Universiti Teknologi Malaysia.

2. Ashkan Khalili (2011). Examining the Relevance of Emotional Intelligence and Organizational Commitment among Employees of Small and Medium Enterprises in Private Sector, International Journal of Business and Management, vol. 6, no. 12, pp. 180-194.

3. Allen, N. J., and Meyer, J. P. (1996). Affective, continuance, and normative commitment to the organization: An examination of construct validity. Journal of Vocational Behavior, 49, 252-276.

4. Barber, M., dan M. Mourshed (2007). How the World's Best Performing Schools Come out on Top. McKinsey \& Company, New York, USA.

5. BPTV (Bahagian Pendidikan Teknik dan Vokasional) (2012). Laporan Tahunan 2012 (2012). Di terbitkan oleh BPTV, KPM.

6. Bishop, W.J., (2000). Support, Commitment and Employee Outcomes in a Team Environment, Journal of Management, 18.

7. Buchanan, B.II (1974). Building organizational commitment: The socialization of managers in work organizations. Administrative Science Quarterly, 19.

8. Christina Boateng (2012). Restructuring Vocational and Technical Education in Ghana: The Role of Leadership Development. International Journal of Humanities and Social Science Vol.2 No.4.

9. Coladarci, T. (1992). Teachers' sense of efficacy and commitment to teaching. Journal of Experimental Education, 60, 323-337.

10. Cohen, A. (1991). Career stage as a moderator of the relationship between organizational commitment and its outcomes; A meta-analysis. Journal of Occupational Psychology.

11. DiPaola, M., Tarter, C.J. and Hoy, W.K. (2005). Measuring organizational citizenship of schools:, the OCB scale, in. Hoy, W. and Miskel, C. (Eds), Educational Leadership and Reform, Vol. 4, and Information Age Publishing, G., CT, pp. 319-41.

12. Dunham, R. B., Grube, J. A. and Castaneda, M. B. (1994). Organizational commitment: the utility of an integrative definition. Journal of Applied Psychology, 79, pp. 370-380.

13. Downs, A. (1991). A case study of the relationship between communication satisfaction and organizational commitment in two Australian organizations. University of Kansas, Lawrence, KS.

14. Elliott, B., and Crosswell, L. (2003). Commitment to teaching: Australian perspectives on the interplays of the professional and the personal in teachers' lives. Paper presented at the International Symposium on Teacher Commitment at the European Conference on Educational Research, Lille, France.

15. Firestone, W., and Rosenblum, S. (1998). Building Commitment in urban high schools. Educational evaluation and policy analysis, 10: $285-299$.

16. Firestone, W and Pennell, J (1993). Teacher Commitment, Working Conditions, and Differential Incentive Policies, Review of Educational Research, 63(4), pp 489-525.
17. Florence F. (2007). Hubungan Tahap Kecerdasan Emosi dengan Tahap Kepuasan Kerja dan Tahap Komitmen Kerjaya di Kalangan Guru Bimbingan dan Kaunseling Sekolah Menengah di Bandaraya Kuching Serawak. UTM.

18. Gamon, C.K. (1991). Managing Commitment: Developing Loyalty in a Changing Workplace. California, Crisp Publications.

19. Hair, Jr., J. F., Black, W. C., Babin, B. J., Anderson, R. E., \& Tatham, R. L. (2006). Multivariate data analysis (6th ed.). Uppersaddle River, New Jersey: Pearson Education International, Inc.

20. Hishamuddin Md. Som (2005). Panduan Mudah Analisis Data Menggunakan SPSS Windows. Skudai, Johor :Universiti Teknologi Malaysia.

21. Iman Ghozali (2008). Model Persamaan Struktural Konsep dan Aplikasi Dengan Program Amos 16.0. Penerbit Universitas Diponegoro Semarang, Indonesia.

22. Iverson, R.D. and Buttigieg, D.M. (1999). Affective, normative, and continuance commitment: can the right kind' of commitment be managed? Journal of Management Studies, Vol. 36 No. 3, p. 307.

23. Jaros, S. J. (1997). An assessment of Meyer and Allenís (1991) three component model of organizational commitment and turnover intentions. Journal of Vocational Behavior, 51, 319-337.

24. Janis Maria Antony (2013). The Influence Of Emotional Intelligence On Organizational Commitment And Organizational Citizenship Behavior. International Journal of Social Science and Interdisciplinary Research ISSN 22773630 IJSSIR, Vol.2 (3).

25. KPM (Kementerian Pendidikan Malaysia) (2011). Pelan Strategik Transformasi Pendidikan Vokasional: Bahagian Pendidikan Teknik danVokasional.

26. Kushman, J. W. (1992). The organizational dynamics of teacher workplace commitment: A study of urban elementary and middle schools. Educational Administration Quarterly, 28, 5-42.

27. Lokman Mohd Tahir, Khadijah Daud \& Rozita Rahmat (2010): Perkaitan Antara Kepimpinan Pengajaran Guru Besar Dengan Kepercayaan dan Komitmen Guru. Jurnal Malaysian Education Dean's Council (MEDC).

28. Lee, R. and Miller, T. (2001). Evaluating the performance of the Lee Carter approach to modeling and forecasting mortality. Demography, 38(4), 537-549.

29. Leithwood, K, Day, C, Sammons, P, Harris, A and Hopkins, D, (2006). Seven strong claims about successful school leadership, Nottingham, National College for School Leadership.

30. Louis, K. S. (1998). Effects of teacher quality of work life in secondary schools on commitment and sense of efficacy. School Effectiveness and School Improvement, 9, 1-27.

31. Lu, C.S., Lai, K., Cheng, T., 2007. Application of structural equation modelling to evaluate the intention of shippers to use internet services in liner shipping. Eur. J. Oper. Res. 180, 845-867.

32. Mathis, R. and Jackson, J. (2003). Human Resource Management. Southem College: Thompson Learning.

33. Matheiu, J.E. and Zajac D.M. (1990). A Review and Meta Analysis of Antecedent, Correletes, and Consequences of Organizational Commitment. Psycological Bulletin 108: pp. 171-194.

34. Metcalf, B., and Dick, G. (2000). Is the force still with you? Measuring Police Commitment. Journal of Managerial Psychology, 15 (8): 812-813. 
35. Meyer, J.P., Allen, N.J. and Smith, C.A. (1993). Commitment to organizations and occupations: Extension and test of a three-component conceptualization. Journal of Applied Psychology, 78.

36. Meyer, J.P., and Allen, N. J. (1997). Commitment in the Workplace: Theory Resesearch and Application. Thousand Oaks, CA: Sage.

37. Mintzberg, H. (1983). Structure in Fives: Designing Effective Organizations, Prentice-Hall, New Jersey.

38. McGregor, D. (2005). The Human Side of Enterprise, Annotated Edition.McGraw Hill.

39. Meyer, J. P. and Allen, N. J. (1984). Testing the side bet theory of organizational commitment: Some methodological considerations. Journal of Applied Psychology, 69, 372-378.

40. Meyer, J.P., Allen, N.J. and Smith, C.A. (1993). Commitment to organizations and occupations: Extension and test of a three-component conceptualization. Journal of Applied Psychology, 78.

41. Meyer, J.P., and Allen, N. J. (1997). Commitment in the Workplace : Theory Research and Application. Thousand Oaks, CA: Sage.

42. Meyer, P. J., Stanley, D. J., Herscovitch, L., and Topolnytsky, L. (2002). Affective, continuance, and normative commitment to the organization: A metaanalysis of antecedents, correlates, and consequences. Journal of Vocational Behavior, 61(1), 20-52.

43. Meyer, J.P. and Allen, N.J. (1991). A three component conceptualization of organizational commitment. Human Resource Management Review, 1, 61-89.

44. Mohamed Mousa and Ruth Alas (2016). Organizational Commitment: A Case Study of Egyptian Teachers PostRevolution. International Journal of Business Administration Vol. 7, No. 4.

45. Mowday, R. T. (1998). Reflections on the Study and Relevance of Organizational Commitment. Human Resource Management Review. 8, 4: 387-401.

46. Mowday, R. T., Steers, R. M., and Porter, L. W. (1979). The measurement of organizational commitment. Journal of Vocational Behaviour, 14, 224-247.

47. Mowday, R., Steers, R., and Porter, L. (1982). Employee organizations Linkages. Dalam P. Warr (eds). Organizational and Occupational Psychology. New York: Academi Press.

48. Nir, A. E. (2002). School based management and its effect on teacher commitment. International Journal of Leadership in Education, 5, 323-341.

49. Norshidah Nordin (2012). Assessing Emotional Intelligence, Leadership Behavior and Organizational Commitment in a Higher Learning Institution. ICTLHE, RCEE, RHED2012.

50. NoraishahDaud (2010) Jaminankerjadanhubungannyadengankepuasankerjadank omitmenterhadaporganisasi. International Conference On Ethics and Professionalism 2010 (ICEP 2010).

51. NoorhafezaHerliani Adey \&FerlisHj. Bahari (2010). Hubungan antara kecerdasan emosi, kepuasan kerja dan komitmen terhadap organisasi. Jurnal Kemanusiaan bil.16.

52. O'Reilly, A.C. (1989). People and organizational culture: A profile comparison approach to assessing personorganization fit. The Academy of Management Journal, 34 (3), 487-516.

53. Potvin, T.C (1991). Employee Organizational Commitment: An examination of its Relationship to Communication Satisfaction and Evaluation of Questionnaires Designed to Measure the Cobstructs. Unpublish doctororal dissertation, University of Kansas, Lawrence, KS.
54. Porter, E. (1974). The contributions of industrial organization to strategic management. The Academy of Management Review, 6, (4), 609-620.

55. Powell D and Meyer J (2004). Side-bet Theory and the Three-component Model of Organizational Commitment, Journal of Vocational Behavior, Vol. 65, pp. 157-177

56. Robbins, S.P., and Judge, T. A. (2007). Organizational Behavior. United States of America: Pearson Education, Inc., publishing.

57. Rosenholtz, S.J. (1989). Teachers' workplace: The social organization of schools. New York: Longman.

58. Rozman Mohd Yusof, Noor Azam Abdul Aziz, Abdul Ghafar Baba and Abd Hair Awang (2010). The Relationship Between Emotional Intelligence And Organizational Commitment Among Employees At Selected Zakat Collection Centres. UiTM.

59. Sahlberg P. (2010). The Secret to Finland's Success: Educating Teachers. Stanford Center for Opportunity in Education.

60. Sanderson, A., Phua, V. C., \&Herda, D. (2000). The American faculty poll. Chicago: National Opinion Research Center.

61. Schappe, S., and Doran, A. (1997). How does fair treatment affect employee commitment to an organization? The Mid-Atlantic Journal of Business, 33(3), 191-201.

62. Stasz, C. and Wright, S. (2004). Emerging policy for vocational learning in England. Will it lead to a better system? London: Learning and Skills Research Centre.

63. Sharifah Shafie, Suhaida Abdul Kadir \& Soaib Asimiran (2013). Beban Tugas Guru Kemahiran Hidup Bersepadu: Isu dan Cadangan, at 3rd Regional Conference on Educational Leadership and Management (RCELAM) 2013 on 19-21 November 2013 at Institut Aminuddin Baki, Genting Highlands, Malaysia.

64. Syed Sofian Syed Salim \& Rohany Nasir (2010). Kesan Kecerdasan Emosi ke atas Tekanan Kerja dan Niat Berhenti Kerja Profesion Perguruan. Volume 5, Number1, 53-68, Jurnal e-Bangi, ms 53-68.

65. Steers, R. (1977). Antecedents and Outcomes of Organizational Behavior. New York: Prentice Hall.

66. Steer, Richard M., and Ulman W. Porter. (1991). Motivation and Work Behavior, Singapore: McGrawHill.

67. Singh, K., and Billingsley, B. S. (1998). Professional support and its effects on teachers' commitment. Journal of Educational Research, 91, 229-239.

68. Vandenberghe, C., and Tremblay, M. (2008). The role of pay satisfaction and organizational commitment in turnover intentions: A two-sample study. Journal of Business and Psychology, 22(3), pp.275-286.

69. Welsch, H. P., and La Van, H. (1981). Inter-relationships between organizational commitment and job characteristics, job satisfaction, professional behavior, and organizational climate. Human Relations, 34, 10791089.

70. Tabachnick, B. G., \& Fidell, L. S. (2007). Using multivariate statistics (5th ed.). Upper Saddle River, NJ: Pearson Allyn \& Bacon.

71. Yahya Don, Aziah Ismail \& Yaakob Daud (2006). Kepimpinan Pembangunan Pelajar Sekolah di Malaysia. Kuala Lumpur. PTS Professional Publishing Sdn. Bhd.

72. Zainudin Awang (2015). Structural Equation Modeling Using AMOS Graphic. Shah Alam: UiTM Press. 